\title{
Identification of VASA Gene Expression in In-vitro Culture From Non-Obstructive Azoospermia (NOA) Testicular Biopsy Cells: A Study to Unlock Knowledge of Male Infertility
}

\author{
Redzuan Abd Razak ${ }^{1,2,3}$, Lokman Md Isa ${ }^{1,3}$, Refaudeen Muhammad Razali ${ }^{2}$, Afzan Mat Yusuf ${ }^{1.3}$, Azantee \\ Yazmie Abd Wahab ${ }^{4,5}$, Syamsul Ahmad Ariffin ${ }^{1}$,Roszaman Ramli ${ }^{4,5}$, Husin Muhammad ${ }^{6}$ \\ ${ }^{1}$ Department of Basic Medical Sciences, Kulliyyah of Nursing, International Islamic University Malaysia (IIUM) \\ Kuantan \\ ${ }^{2}$ Department of Biomedical Science, Kulliyyah of Allied Health Sciences, IIUM Kuantan \\ 3 IIUM Human Cellular and Molecular Biology Research Cluster (iMolec), IIUM Kuantan \\ ${ }^{4}$ Department of Obstetrics \& Gynaecology (O\&G), Kulliyyah of Medicine, IIUM Kuantan \\ ${ }^{5}$ IIUM Fertility Centre, IIUM Kuantan \\ ${ }^{6}$ Institute for Medical Research, Jalan Pahang, 50588 Kuala Lumpur, Malaysia
}

\begin{abstract}
The expression product of VASA gene is widely conserved germ line marker and participates to regulate the development of reproductive system and spermatogenesis in healthy man. Azoospermic is a condition which the man is unable to produce any sperm cells for reproduction activity. This condition produced has bad impact to the man since the ability to produce their own progeny will be interrupted or blocked forever. Not only the family bloodline of the man would be ended, the psychological issue like shamefulness and low self-esteem occurs. In Islam, seeking knowledge is an obligatory to Muslims in order to solve problems and improve lives. Thus to unveil the problem of azoospermic man we aimed to determine the level of VASA gene expression in samples of testes cells of non-obstructive azoospermic (NOA) and compare it with sperms of healthy man. Samples were taken from three NOA patients by testicular sperm extraction (TESE) to obtain testicular biopsies. Testicular cells were isolated and cultured in supplemented knockout DMEM media. VASA gene expression was determined by reverse transcriptase polymerase chain reaction (RT-PCR). The VASA gene expression from sperm of healthy man was also determined for comparison purpose. It was demonstrated that the addition of growth factor significantly increased SSC-like cells colony formation in tissues obtained from NOA patients. No VASA expression was detected in spermatogonial-like stem cells culture on day 1, 7, 14 and 21 in each of the azoospermic samples. Our findings shown VASA gene was not expressed in spermatogenesis in vitro culture that might be associated with the abnormal differentiation of primordial germ cells that lead to male infertility. Islam also teaches us to not have feelings of despair and for problems that we are facing but to find the solution and consider the problem as a test from the Almighty. All the tests should be handled with strong believe since only Allah (SWT) knows what the best for us and each of the tests will have justified wisdom and benefits which we as human being are unable to realise thoroughly.
\end{abstract}

KEYWORDS: VASA, non-obstructive azoospermia, spermatogenesis, testicular cells, justified wisdom

\section{INTRODUCTION}

About 10 to $15 \%$ in general population, couples suffer due to infertility problems. ${ }^{5}$ Roughly, $50 \%$ of these cases can be attributable to issues in the male partner. Of these infertile men, 10 to $20 \%$ of all men suffer from azoospermia.There are two etiologies of azoospermia known as non-obstructive azoospermia

Corresponding author:

Muhammad Lokman Md Isa

Department of Basic Medical Sciences,

Kulliyyah of Nursing,

IIUM Human Cellular and Molecular Biology Cluster

(iMoleC),

International Islamic University Malaysia,

Jalan Sultan Ahmad Shah, 25200 Kuantan, Pahang

Telephone: +60129645581

Email: lokman@iium.edu.my
(NOA), a lack of spermatozoa production in the testes, and obstructive azoospermia (OA), an inability of produced spermatozoa to reach the emitted semen. From the total amount of azoospermic men, it is estimated that $49 \%$ to $93 \%$ caused by NOA. ${ }^{19}$ NOA is due to a failure of spermatogenesis process. This condition produces bad impact to the man since the ability to produce their own progeny will be interrupted or blocked forever. Not only the family bloodline of the man will cease the psychological issue like shamefulness and low self-esteem will be experienced by the sufferer.

In Islam, seeking knowledge is an obligatory to each Muslims in order to solve problems and live better. Problem should be solved by finding solutions and wise decision. But somehow, there 
are problems that sometime better left unsolved since no better solution could be achieved e.g. azoospermic in men. When a man has been diagnosed as azoospermic patient, there is no more possibility for him having his own biological offspring, and no solution is available. Such thought is against Islamic principles, which asks the humans to find the solution as what the Prophet (PBUH) said, "go and gain knowledge starting from birth till die. Therefore male azoospermic problem should be considered as unsolved problem that is waiting to be discovered.

Spermatogenesis is a cellular differentiation process that produces spermatozoa in which diploid spermatogonia differentiate to haploid spermatozoa through meiotic reduction. ${ }^{7}$ There is major interest in the field of andrology to understand the selfrenewal and germ-associated networks of human adult spermatogonial stem cells (SSCs). The establishment and improvement of in vitro culture of SSCs has provided important information about germ cell biology and future fertility treatment for azoospermia patients. ${ }^{5}$

Current knowledge regarding the molecular markers of SSCs is still limited. This is due to the rarity of human testicular tissue, the relatively low number of adult stem cells in the testis, the lack of unique surface markers, and the absence of a robust proliferative in vitro culture system to support their self-renewal for efficient isolation and high purity propagation. ${ }^{5}$ It is estimated that more than 2000 genes are involved in the regulation of spermatogenesis. ${ }^{4}$ Lately, it has been proclaimed that the VASA gene has turned into hereditary determination germ-cell line marker derived from undifferentiated embryonic cells. ${ }^{22}$ VASA expression is limited to the testis and ovary, and is unnoticeable in somatic tissues. ${ }^{4}$ VASA protein is specifically limited to polar granules and then specifically exhibited during the whole of germ cell stages. ${ }^{12}$ Earlier studies indicated that VASA were detected in spermatids, spermatocytes and spermatogonia. According to Castrillon et.al (2000), no sign was noticed in testicular biopsies from a sterile patient with Sertoli cell only syndrome thus VASA is a possible gene marker for male infertility. Therefore this study is to determine the present of VASA gene expression in NOA patient using RT-PCR. This finding may help to discover the male fertility problems.

\section{MATERIAL AND METHODS}

\section{Sample collection}

Testicular biopsy tissues were obtained from the TESE procedure at International Islamic University Malaysia (IIUM) Fertility Centre, IIUM Malaysia. The use of human testicular biopsies and the experimental protocol were ethically approved by the IREC, IIUM (IIUM/305/20/4/10/1). For controls, semen samples were obtained by masturbation with signed informed consent and analysis and performed according to World Health Organization (WHO) criteria.

\section{Isolation of Human Spermatogonial Stem Cells and} In vitro Culture

The testicular biopsy tissues were washed with sperm washing media (Irvine Scientific, USA). The testicular tissues were minced into small pieces and digested with $2 \mathrm{ml}$ trypsin for 20 minutes in $37^{\circ} \mathrm{C}$ temperature. An amount of $2 \mathrm{ml}$ of Basic human embryonic stem cell (bhESC) media was added to deactivate the function of trypsin and the cells were released into solution. Then, the dissociated cells were collected by centrifugation at $800 \mathrm{rpm}$ for 5 min. Briefly, testes tissues were placed in bhESC media which consists of knockout Dulbecco's Modified Eagle's Medium EM medium (DMEM; Gibco, Paisley, UK), knockout serum replacement, Lglutamine + 2-mercaptoethanol, 100x non-essential amino acids, recombinant basic fibroblast growth factor (bFGF) (Sigma, St Louis, MO), and gentamycin (Gibco, Paisley, UK).

The collected cells were incubated in a humidified atmosphere at $37{ }^{\circ} \mathrm{C}$ and $5 \% \mathrm{CO}_{2}$. The cells were cultured in uncoated 24-well culture plates (ColeParmer, Vernon Hills, Illinois) and the culture medium was replaced for every 3 days. In order to propagate the clusters and prevent SSCs from differentiating, cells were passaged every 5-7 days, with trypsin- EDTA (Invitrogen) and re-cultured. The culture was studied using an inverted microscope (Zeiss, Jena, Germany). The resulting cells were collected on different day of culture at 1, 7, 14, and 21 days for RT-PCR analysis.

\section{Identification of VASA gene expression}

Total RNA from the control sperm samples, and culture of testicular cells were extracted using PureLink ${ }^{\circ}$ RNA Mini Kit (life tecnologies, USA). The quantification and the purity of RNA was checked by a 260/280 nm ratio measurement by using NanoDrop Spectrophotometers (NanoDrop Technologies, Inc., Wilmington, DE, USA). First-strand CDNA was performed by using oligodT primers and SuperScript $\circledast$ III First-Strand Synthesis System for RT-PCR Kit. All reverse transcription reagents were purchased from Invitrogen (USA). Samples were then reverse transcribed at $42^{\circ} \mathrm{C}$ for 15 minutes and denatured at $99^{\circ} \mathrm{C}$ for 10 minutes. After that procedure, the $\mathrm{CDNA}$ was stored at $-80^{\circ} \mathrm{C}$ before use for amplification by PCR.

VASA primer sequence was taken from previous study by Medrano et al. (2010). The primers specific for VASA were designed using previously described human sequences (GenBank) (Table 1). PCR products were validated by sequencing in all cases.

RT-PCR was performed using the prepared CDNA, the primers, and TopTaq DNA Polymerase (Qiagen). Firstly, dNTP mix and primer solutions were thawed at room temperature. The PCR master mix was prepared consist of; 10x TopTaq PCR Buffer, dNTP $\operatorname{mix}(10 \mathrm{mM}$ of each), 10x Coral Load concentrate, 
primer forward, primer reverse, RNase-free water and cDNA. The tubes containing master mix were briefly centrifuged to assure all the mixtures were well mixed. The PCR tubes were placed in Techne TC-512 Thermal Cycler to run the samples. The RTPCR protocols were started by denaturation step at $94^{\circ} \mathrm{C}$ for 30 seconds, followed by annealing step at $55.0^{\circ} \mathrm{C}$ for 30 seconds and final extension step at $72^{\circ} \mathrm{C}$ for 1 minute for 35 cycles. The bands were visualized by gel electrophoresis at $120 \mathrm{~V}$ for voltage 40 minute by using EC 300 XL Power Supply.

Table 1.Primer Sequence used for measuring VASA expression.

\begin{tabular}{|c|c|c|c|c|}
\hline Gene & Primer Sequences (5'-3') & $\begin{array}{l}\text { Annealing } \\
\text { temperature }\left({ }^{\circ} \mathrm{C}\right)\end{array}$ & Size (bp) & $\begin{array}{l}\text { GenBank } \\
\text { accession no. }\end{array}$ \\
\hline VASA & $\begin{array}{l}\text { Forward primer: } \\
\text { 5'-ATGGATGATGGACCTTCTCG-3' } \\
\text { Reverse primer: } \\
\text { 5'-CCTCTGTTCCGTGTTGGATT-3' }\end{array}$ & 54.1 and 55 & 228 & $\begin{array}{l}\text { NM_024415.2 } \\
\text { (positions } 228 \\
\text { and 456) }\end{array}$ \\
\hline
\end{tabular}

\section{RESULTS}

In this study, a small portion of adult human testicular biopsy cells obtained from (NOA) patients were cultured. This study demonstrated that the addition of growth factor significantly increased SSC -like cells colony formation in tissues obtained from NOA patients. It was also shown that these SSC-like cells clusters managed to grow and propagated for 3 weeks of culture (21 days). The addition of basic fibroblast growth factor (bFGF) in the supplemented knockout DMEM, increased the numbers of SSC-like cells clusters by self-renewal in vitro (Fig. 1).

This study had shown that VASA gene was detected in normozoospermic man as a control. However, there is no expression of VASA gene in NOA samples on day 1, day 7, day 14, and day 21 of cultures (Fig. 2).

\section{DISCUSSION}

This study demonstrated that the addition of growth factor significantly increased SSC-like cells colony formation in tissues obtained from NOA patients. It was also shown that these SSC-like cells clusters can be successfully cultured and propagated for 3 weeks (21 days). This is supported by Ebata et.al. (2011) showed that cluster disassociation and serial passaging for prolong periods can increase the SSCs in number. In this study, the addition of basic fibroblast growth factor (bFGF) in supplemented knockout DMEM, increased the numbers of SSC-like cells clusters by self-renewal in vitro (Fig. 1).

This study has also shown that VASA gene was detected in normozoospermic man (as a control. This finding is consistent with Guo et al. (2007) that verified that VASA was expressed in human ejaculated sperm, and its expression was notably declined in the infertile patients, those with oligozoospermia. The statement above correlates with the finding of this research that there was no expression of VASA on day 1 , day 7 , day 14 , and day 21 on NOA samples. These patients may have a complete depletion of the spermatogenic process, so the expression of VASA are reduced or terminated totally until it almost disappears. Normally, the expression in the spermatogenesis enters the meiotic stage.

Growth factors in a culture medium may also play an important role in differentiating cells into other stages. In our study, the use of only one growth factor; bFGF in bHESC and in short term of culture was not enough to propagate SSCs. Most of other studies emphasized that combination of growth factor instead of one, have greater impact to induce differentiation to a precursor of spermatogenesis. Growth factors included in that modified medium, i.e., basic fibroblast growth factor (bFGF), epidermal growth factor (EGF), glial cell linederived neutrophic factor (GDNF) and leukemia inhibitory factor (LIF), have the ability to induce spermatogonial stem cell differentiation and survival. ${ }^{20}$ Ebata et al. (2011), which stated that the combination of fibroblast growth factor 2 (FGF2) and GDNF had propagated the number of dividing SSCs opposed to a no-growth-factor condition. It means that combination of growth factors may promote a differentiation pattern of SSCs that sustains the size of the stem cell pool while producing committed predecessor. Another study also supported that growth factor play a vital role in differentiation pattern. Ardekani et al. (2009) stated that they used a special formulated culture medium to support the SSCs development. Lim et al. (2010) stated that combination of growth factors such as GDNF, FGF and EGF in long-term culture has improved propagation of SSCs in NOA and OA patients. It has been unclear how growth factors contribute in controlling the patterns of SSCs division and fate decision. Since a SSCs vital function is to support the differentiation of spermatogenic and transmission of genes to the next generation, it is possible that growth factor may induce division of SSCs that cause the production of progenitors.

The least discovery of azoospermic condition in men, teach us how grand is the knowledge of the Almighty Allah (SWT). Islam also teaches us to not feel despair and give up when facing any problem, but find a solution and consider the problem as a 
test from the Almighty. All the tests should be handled carefully with strong believe since only Allah (SWT) knows what the best for us and each of the tests will have justified wisdom and benefits which we as human being are unable to realise thoroughly. In order to helps men who are azoospermic, more research needs to be done and thus help such men in the population from alleviating their anxiety in order to have a child through sperm donation or some other way that are not forbidden in Islam but popular in the Western world.

\section{CONCLUSION}

Our finding shown that VASA gene was not expressed in spermatogenesis in vitro culture that might be associated with the abnormal differentiation of primordial germ cells that lead to male infertility. In order to helps the men with azoospermic condition, more profound needs to be done. Be aware that Islam also teaches us not to despair and give up, but try to solve problems and consider such problems as a test from the Almighty.

\section{ACKNOWLEDGEMENTS}

The authors are very grateful to the management and technical staffs of IIUM, Fertlity Centre for their kind cooperation. The technical assistance from laboratory assistants of Integrated Centre for Research Animal Care and Use (ICRACU) is highly appreciated.

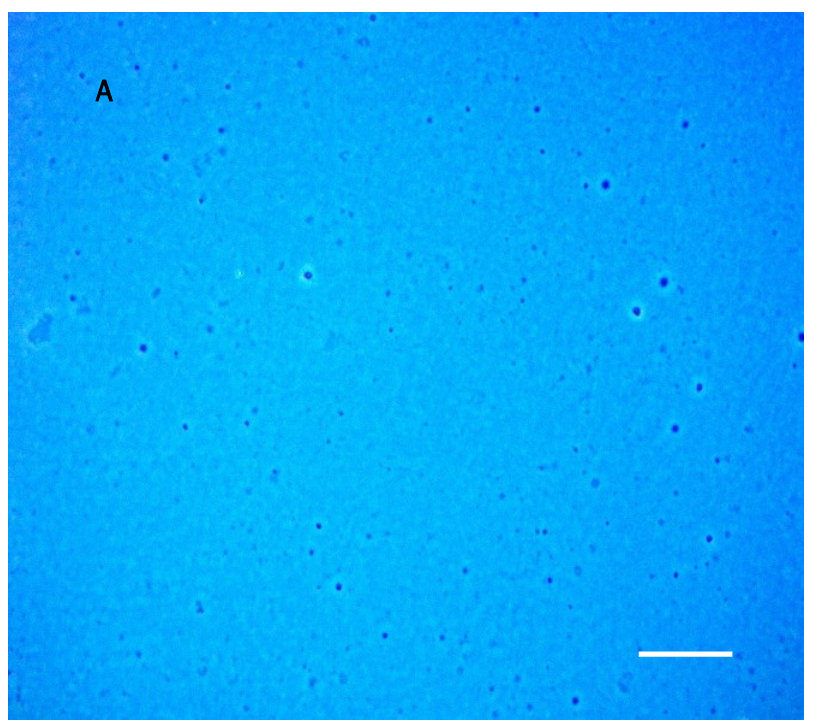

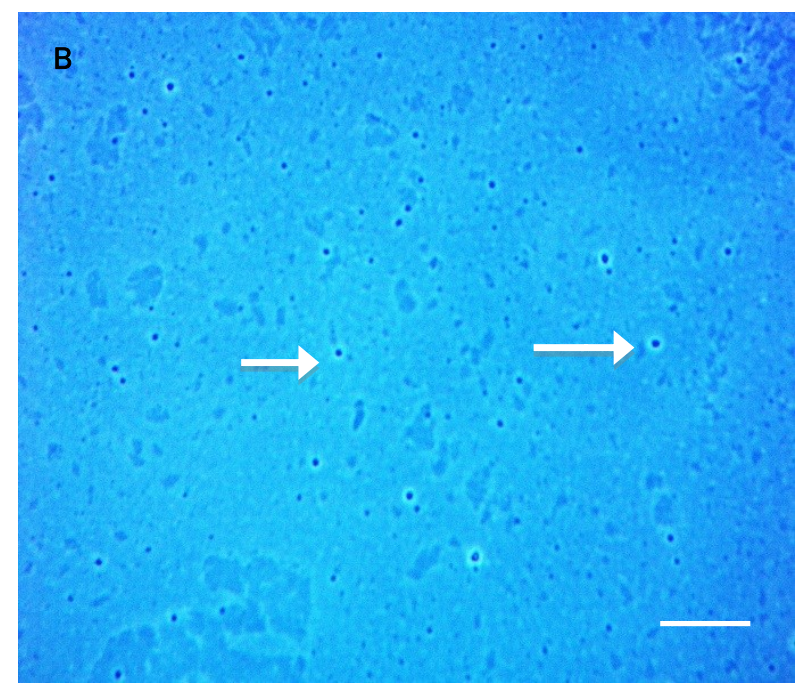
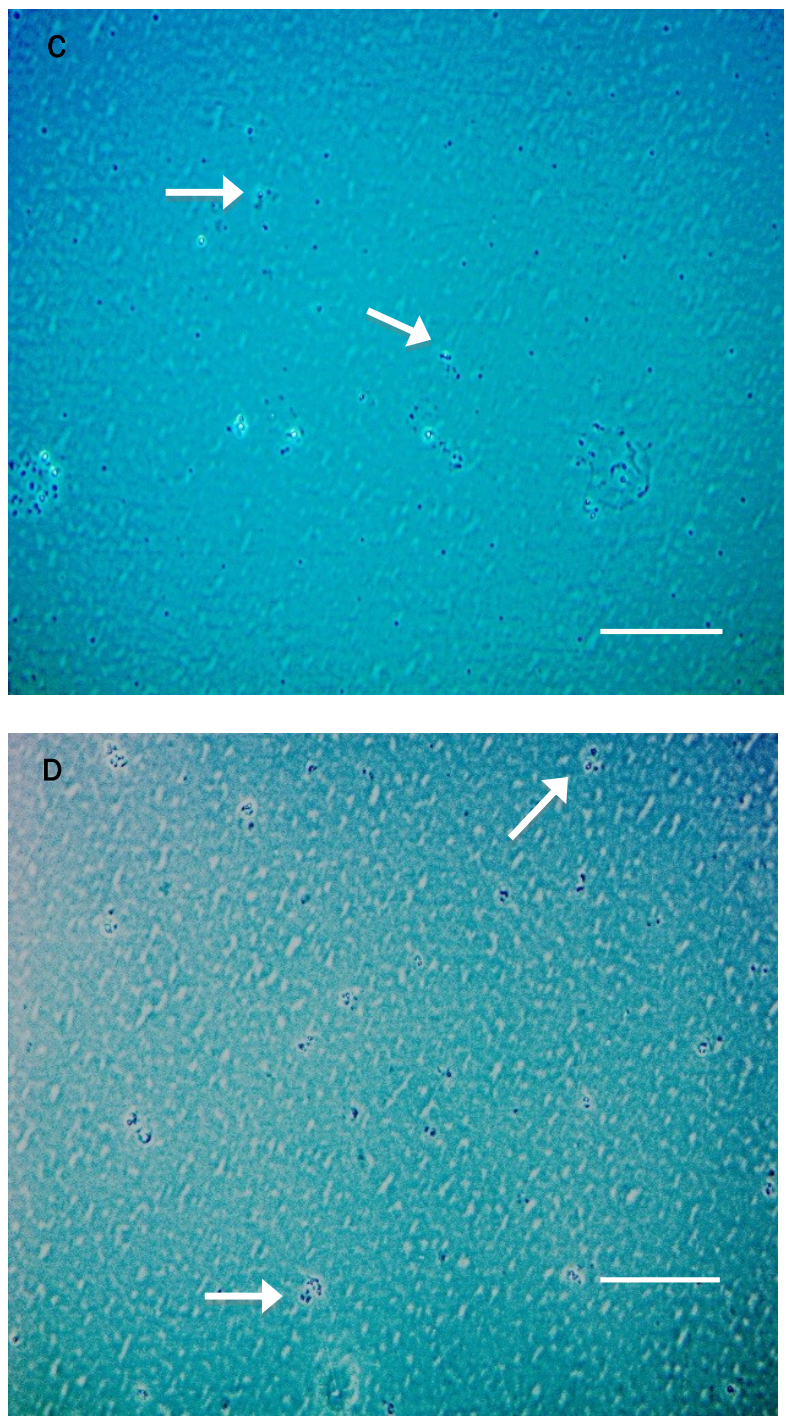

Figure. 1. Propagation activity of SSCs in vitro culture condition.A: $24 \mathrm{~h}$ culture, SSCs adhered to the culture plate; B: Day 7, SSCs were seen as round or oval shape (arrows); C: Day 14, SSC started to form colony (arrows); D: SSC colonies (arrow) after 21 days of culture. Scale bars $=324 \mu \mathrm{m}(\mathrm{A}), 198 \mu \mathrm{m}(\mathrm{B}), 590 \mu \mathrm{m}(\mathrm{C}), 408 \mu \mathrm{m}(\mathrm{D})$ and $324 \mu \mathrm{m}(\mathrm{E})$. The cells were observed under inverted microscope (200X). 


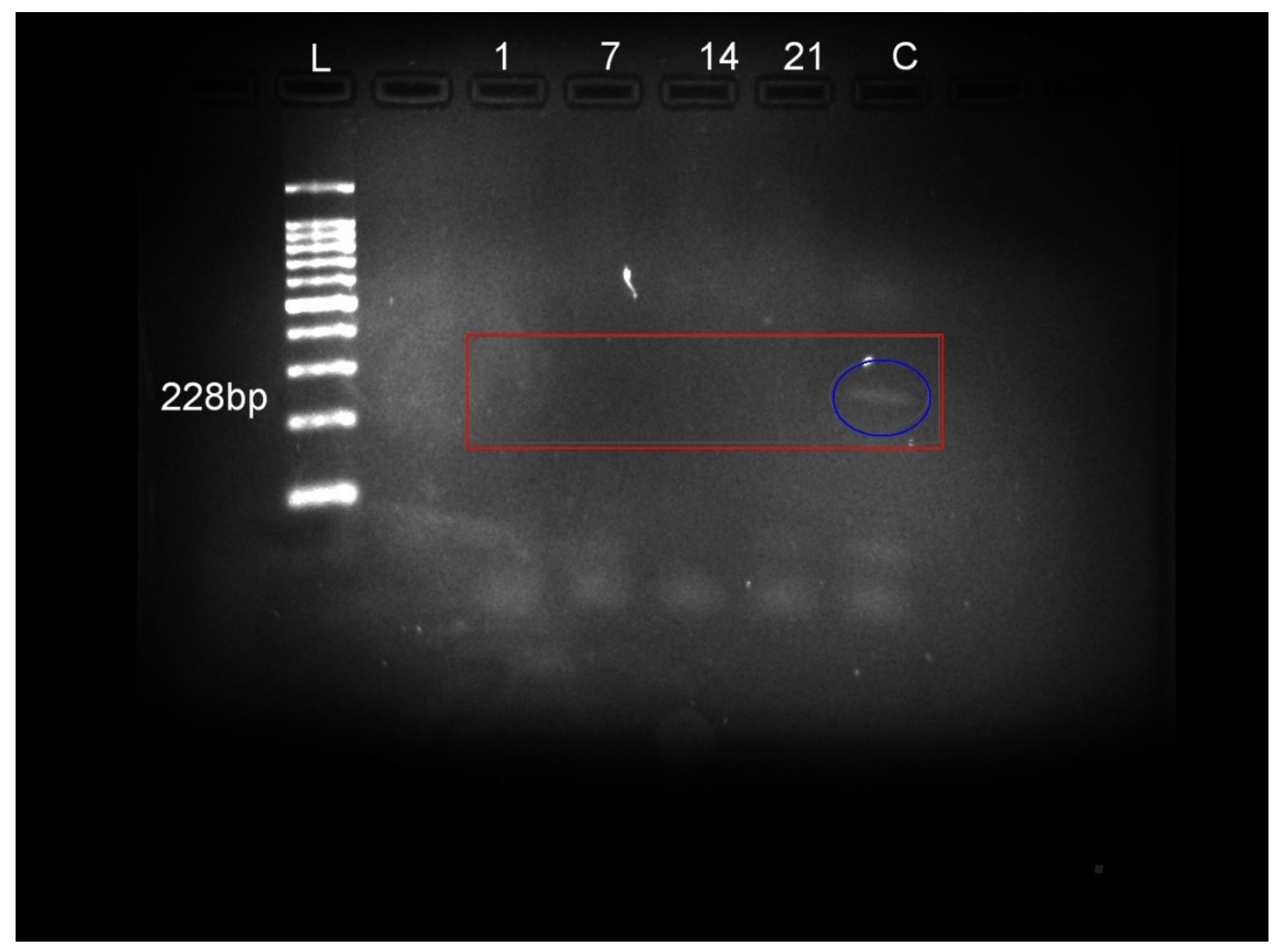

Figure. 2. Representative gels of RT-PCR amplification products of VASA (228 bp) for each sample of testis biopsy culture. $L$ is indicator for $100 \mathrm{bp}$ ladder marker which is on the left.

\section{REFERENCES}

1. Aponte P, Soda T, Teerds K, Mizrak S, Kant H, Rooij D. Propagation of bovine spermatogonial stem cells in vitro. Reproduction. 2008;543557.

2. Ardekani HS, Mizrak SC, Daalen SKM, Korver CM, Gajadien HLR, Koruji M, Hovingh S, Reijke TM, Rosette JJMCH, Veen F, Roiij DG, Repping $S$, Pelt AMM. Propagation of human spermatogonial stem cells In Vitro. JAMA. 2009;2127-2134.

3. Brinster RL. Germline stem cell transplantation and transgenesis. Science. 2002;2174 - 2176.

4. Castrillon HD, Quade BJ, Wang TY, Quigley C, Crum CP. The human VASA gene is specifically expressed in the germ cell lineage. Proc. Natl. Acad. Sci. USA. 2000;9585 - 9590.

5. Conrad S, Azizi H, Hatami M, Kubista M, Bonin $M$, Hennenlotter J, Renninger M, Skutella T. Differential gene expression profiling of enriched human spermatogonia after shortand long-term culture. BioMed Research International. 2014: 1-17.

6. Culty M. Gonocytes, the forgotten cells of the germ cell lineage. Embryo Today. 2009;1-26.

7. Ebata K, Yeh J, Zhang X, Nagano M. Soluble growth factors stimulate spermatogonial stem cell divisions that maintain a stem cell pool and produce progenitors in vitro.

Experimental Cell Research. 2011;1319-1329.

8. Fujiwara H, Fukuoka M, Yasuda K, Ueda M,
Imai K, Goto Y, Suginami H, Kanzaki H, Maeda M, Mori T. Cytokines stimulate dipeptidyl peptidase-IV expression on human luteinizing granulosa cells. J. Clin. Endocrinol Metab. 1994;1007-1011.

9. Goharbakhsh L, Mohazzab A, Salehkhou S, Heidari M, Zarnani AH, Parivar K, Akhondi MM. Isolation and culture of human spermatogonial stem cells derived from testis biopsy. Avicenna Journal of Medical Biotechnology. 2013;5(1): 5461.

10. Gruidl ME, Smith PA, Kuznicki KA, McCrone JS, Kirchner J, Roussell DL, Strome S, Bennet KL. Multiple potential germ-line helicases are components of the germ-line-specific $P$ granules of Caenorhabditis elegans. Proc. Natl. Acad. Sci. USA. 1996;1313837-13842.

11. Guo X, Gui YT, Tang AF, Lu LH, Gao X, Cai ZM. Diferential expression of VASA gene in ejaculated spermatozoa from normozoospermic men and patients with oligozoospermia. Asian J Androl. 2007;339-344.

12. Hay B, Jan LY, Jan YN. Localization of vasa, a component of Drosophila polar granules, in maternal-effect mutants that alter embryonic anteroposterior polarity. Dev. 1990;109(2):42533.

13. Jun LH, Ning Y, Yu ZX, Wei J, Zhong LH. Spermatozoal protein profiles in male infertility with asthenozoospermia. Chinese Medical Journal. 2010;2879-2882. 
14. Koruji M, Shahverdi A, Janan A, Piryaei A, Lakpour MR, Sedighi MG. Proliferation of small number of human spermatogonial stem cells obtained from azoospermic patients. J Assist Reprod Genet. 2012;957-967.

15. Kossack N, Meneses J, Shaishefi, Nguyen HN, Chavez S, Nicholas C, GromollJ, Turek PJ, ReijoPera RA. Isolation and characterization of pluripotent human spermatogonial stem cell derived cells. Issue Stem Cells. 2009;138-149.

16. Lim JJ, Sung SY, Kim HJ, Song SH, Hong JY, Yoon TK, Kim JK, Kim KS, Lee DR. Long-term proliferation and characterization of human spermatogonial stem cells obtained from obstructive and non-obstructive azoospermia under exogenous feeder-free culture conditions. Cell. Prolif. 2010;43:405-417.

17. Medrano JV, Marques-Mari Al, Aguilar CE, Riboldi M, Gariddo N, Martinez-Romero A, O'Connor E, Gil-Salom M, Simon C. Comparative analysis of the germ cell markers c-KIT, SSEA-1, and VASA in testicular biopsies from secretory and obstructive azoospermias. Mol. Hum. Repro. 2010;811-817.

18. Noce T, Okamamoto IS, Tsunekawa N. Vasa homolog genes in mammalian germ cell development. Cell.Struct.Funct. 2001;131-136.

19. Pastore AL, Palleschi G, Silvestri L, Leto A, Carbone A. Obstructive and Non-Obstructive Azoospermia. 1-21, 2012.

20. Shinohara MK, Toyokuni S, Ogonuki N, Inoue K, Miki H, Ogura A, Shinohara T. Long-Term Proliferation in Culture and Germline Transmission of Mouse Male. Biol. of Repro. 2003;612-616.

21. Tanaka SS, Toyooka Y, Akasu R, Katoh-Fukui Y, Nakahara $Y$, Suzuki R, Yokoyama M, Noce T. The mouse homolog of Drosophila Vasa is required for the development of male germ cells. Genes. Dev. 2000;841-853.

22. Toyooka Y, Tsunekawa N, Akasu R, Noce T. Embronic stem cells can form germ cells in vitro. PNAS. 2003;11457-11462.

23. Toyooka Y, Tsunekawa N, Takahashi Y, Matsui Y, Satoh M, Noce T. Expression and intracellular localization of mouse Vasa-homologue protein during germ cell development. Mech.Dev. 2000;139-149. 